\title{
IMPROVING STUDENTS' PARTICIPATION IN SPEAKING ENGLISH USING SNOWBALL THROWING TECHNIQUE
}

\author{
${ }^{1}$ Maulani Nurmalasari, ${ }^{2}$ Yanuarti Apsari \\ IKIP SILIWANGI \\ 1․mallamamal1158@gmail.com, ${ }^{2}$ yanuar.apsari1@gmail.com
}

\begin{abstract}
This study aimed to investigate the implementation of snowball throwing technique in teaching speaking and to find out the students' participation toward the implementation of snowball throwing. This study was conducted at SMK PGRI 1 Cimahi. The students of XI AP 1 class were selected as the respondents of the research. The research used descriptive qualitative method. The data was obtained from classroom observation and students' interview. The result showed that snowball throwing technique can be used effectively to improve students' speaking skill through several stages. First, every leader explains the material to their group. Second, every student writing one question about the material. Third, the paper is rolled into a ball and thrown from one student in a group to the other student in another group for approximately 2 minutes. Fourth, after the student gets one ball (one question), he or she is given chance to answer the question. Fifth, every group has their turn to answer the question; the group that gave wrong or incorrect answers and gets the lowest score is given a penalty. Those stages gave the students more chance to interacted in the class. It was very helpful in provide the students with more enjoyable activities which made the students involved in teaching and learning process actively.
\end{abstract}

Keywords: Students Participation; Snowball Throwing.

\section{INTRODUCTION}

Students' participation are divided into active and passive participation. Murray and Lang (1997) as cited in (Aprila, 2017) stated that students who participate actively in the classroom will in fact learn the subject matter more effectively than students that are taught in the traditional lecture mode. Students active participation also be able to make an active learning.

Active learning occured when students are mentally involved, when students engange in handson activities, when students are involved in a process of inquiry, discovery, investigation, and 
interpretation. Therefore, Bransford, Brown, and Cocking (2000) as cited in (Tesfaye \& Berhanu, 2015) stated that learning is enhanced when students repeat the information in their own words or when they give examples or make use of the information.

Based on Mustapha and Abd Rahman (2011) as cited in (Aprila, 2017), there are some objectives that can be used for assessing participation, they are: 1) Initiate interaction whenever appropriate, 2) Spontaneity, 3) Not affraid to challenge others' idea, 4) Able to defend own ideas, 5) Elaborate answer, 6) Show confidence, 7) High interaction with classmates, 8) Tend to participate to help classmate out, 9) Interact with teacher or peers when they need help, and 10) Pay attention.

Since students' active participation give the important role to determine the success of the learning process, the teacher should choose an effective teaching method or technique which is trusted to improve students active participation in the class. There are a lot of teaching techniques that can be used by the teacher, one of them is Snowball Throwing technique.

Snowball Throwing is a method learning that started with formation group that started from chairman group for get a task from the teacher, then all of students make a question that formed like as ball (question paper) then throwing with another students,after that will be anwer question from the ball that get it (Mukhtari, $2010: 6$ ) as cited in (Nuryati, Antoni, \& Erippudin, 2015) . Meanwhile Darusmin, Delfi, and Masyhur (2012) as cited in Apsari (2018) defined snowball throwing as one modification of an interesting game that is mutually throwing snowballs which contains questions to fellow friends which focuses on the ability to formulate question.

Another expert, Suprijono (2010 : 33) as cited in (Nuryati et al., 2015)states that snowball throwing is a technique that requires active students in teaching and learning activities. In this teaching technique of each student create two distinct groups. Each group represented materials provided by teachers. The material is also not far from what has been given by teachers to the students.

According to Istarani (2012) and Suprijono (2013 as cited in (Apsari, 2018), some steps of implementing snowball throwing technique are as follows.

1. Teacher extends the material.

2. Teacher forms the students into groups, and calls each leader of the group to give explanation about the material.

3. Each group leader comes back to their group and explains the material to their group.

4. Every student is given one worksheet for writing one question about the material explained by the group leader.

5. For each group there are three questions; the paper is rolled into a ball and thrown from one student in a group to the other student in the other group for approximately 2 minutes. 
6. After the student gets one ball (one question), he or she is given chance to answer the question.

7. Every group has their turn to answer the question; the group that gave wrong or incorrect answers and gets the lowest score is given a penalty.

8. Conclusion.

9. Evaluation.

Based the explanation above, snowball throwing technique is an teaching technique that require the students to participate actively in the classrom. Thus, this study is aimed to find out the effectiveness of snowball throwing technique to improve students active participation.

\section{METHOD}

In this study, researcher used qualitative descriptive method. According to Sandelowski, as cited in (Lambert \& Lambert, 2012), qualitative descriptive research should be seen as a categorical, as opposed to an non-categorical, alternative for inquiry. Qualitative descriptive studies are the least "theoritical" of all of the qualitative approaches to research. In addition, qualitative descriptive studies are the least encumbered studies, compared to other qualitative approaches, by a pre-existing theoritical or philosophical commitment.

This study was conducted in SMK PGRI 1 Cimahi with the participants of the study was the students of XI AP 1 class. The data of the study were obtained from classroom observation and interview.

Observation is the systematic description of the events, behaviours, and artifacts of a social setting (Marshall \& Rossman, 1998, p.79) as cited in (Kawulich, 2012). The observation was used to get the information regarding the implementation of snowball throwing technique during the lesson. The specification of the observation used by the researcher is as follows:

Table 1. Specifications for Performance

\begin{tabular}{ll}
\hline \multicolumn{1}{c}{ Objectives } & \multicolumn{1}{c}{ Indicators } \\
\hline Initiated interaction whenever appropriate & $>$ Share their ideas \\
\hline Able to defend own ideas & $>$ Can answer or give reasons about their \\
& ideas/opinions \\
\hline Show confidence & $>$ Not hesitate or rush \\
\hline High interaction with clasmates & $>$ Share their opinions with their peers \\
& $>$ Ask the questions to their peers \\
\hline Pay attention & $>$ Give verbal or non-verbal respond \\
\hline & $>$ Listen to others when they talk \\
\hline
\end{tabular}


Meanwhile, the interview was used to obtain the deeper information concerning the students' perception which is not accessible through the observation. Kvale (1996: 174) as cited in (Alshenqeeti, 2014) stated that interview is "a conversation, whose purpose is to gather descriptions of the life-world of the interviewee" with respect to interpretation of the meanings of the 'described phenomena'. The interview was conducted to 6 students of XI AP 1 class, they are the students with different level of participation in the class.

\section{RESULTS AND DISCUSSION}

\section{Results}

In this result, the data from interview was elaborated below. The data from interview is as follows.

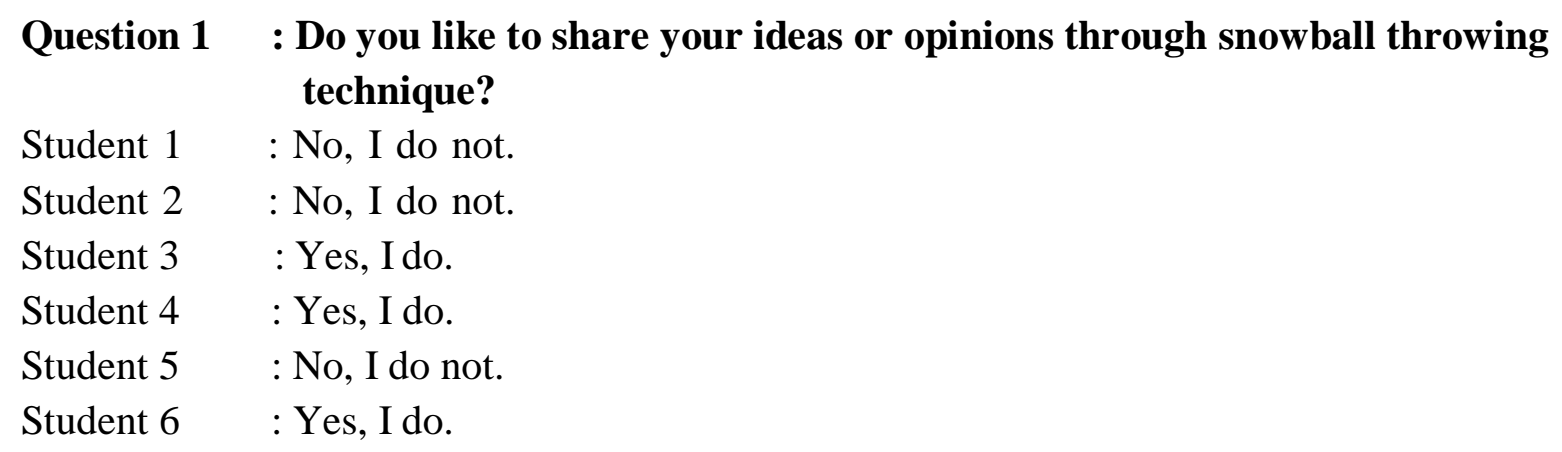

Question 2 : Do you like to answer the question when you get the ball?

Student 1 : No, I do not.

Student 2 : Sometimes, if I can answer that.

Student 3 : Yes, if I able to answer.

Student 4 : No, I do not.

Student 5 : No, I do not.

Student 6 : No, I do not.

\section{Question 3 : How can you explain your opinions?}

Student 1 : Uhm, with telling my peers.

Student 2 : With tell it to my friends

Student 3 : With raise my hand and ask for permission to the teacher to explain my opinion.

Student 4 : Ask for permission to the teacher.

Student 5 : I dont like to explain my opinion.

Student 6 : Ask for permission to the teacher for give the opinion and explain that.

\section{Question 4 : Do you feel confident to talking in front of your classmates through snowball throwing? \\ Student 1 : No. I do not.}


Student 2 : Sometimes.

Student 3 : Yes, I do.

Student 4 : I felt confident rarely.

Student $5 \quad$ : No, I do not. I felt shy when I talked in front of them.

Student 6 : Honestly, no.

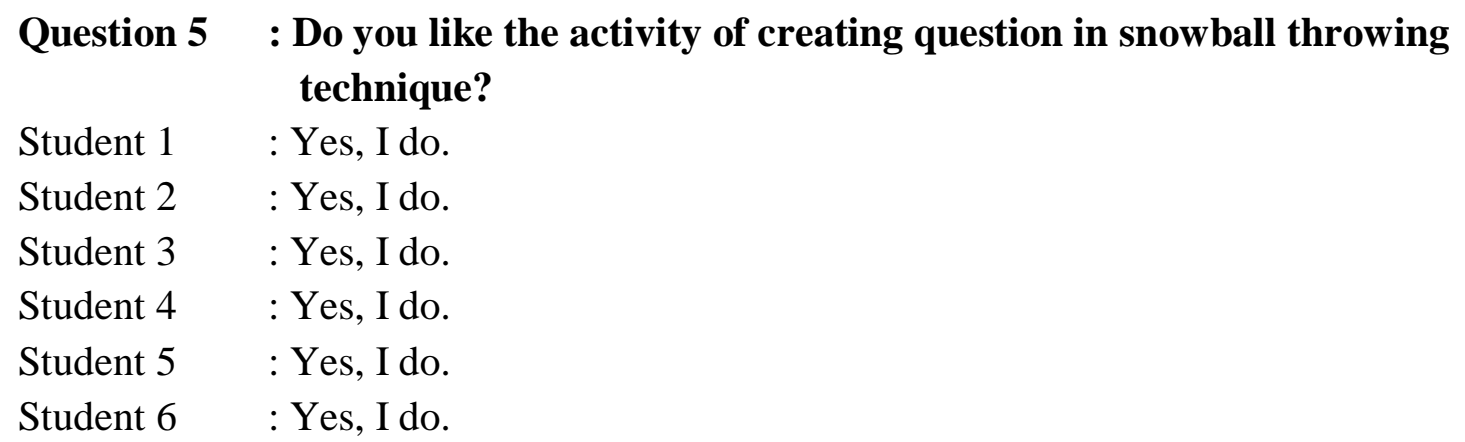

Question 6 : Do you think that snowball throwing technique help you to be active in the class?

Student 1 : Yes, because I should follow the game and it was fun.

Student 2 : Yes, because I should thrown the ball and answer the question.

Student 3 : Very helpful because not only made the learning process fun, the technique also require me and others to answer the question directly.

Student 4 : Yes, because it was fun and made me enjoyed the lesson, so I can more active in the class.

Student $5 \quad$ : Yes, because it was a game and all of us should involved.

Student 6 : Yes, very helpful because I should follow the rules of the game. The technique also made the learning process fun and enjoy.

\section{Discussion}

From the data interview, all respondent said that snowball throwing technique can improve students' paticipation in speaking class. It is supported by the data from classroom observation. The improvement is described as follows:

In the first meeting, most of the students were still passive during the learning process. Half of the students in the class participated actively and the rest being a passive participants. Altough some of the students did not contribute in participated actively, they still paid attention and did the command ftom the teacher. They followed the rules of the techniques and answered the question briefly. They also asked the teacher when they felt confused about certain thing, like the kind of the question or how the rules of the game will be implemented. The students also helped their friend to made a question and helped them with vocabularies. In spite of the students were still passive, the learning process continues well. 
In the second meeting, most of the students paritipated more actively compared with the firs meeting. Most of the students interacted more actively started from the beginning of the class. The students also could refuted others' opinion. For example, when the student gave the wrong answer to the question, the other student refuted by saying:

A : "No, I dont think so. I think your answer is wrong. The first part of analytical exposition text is thesis"

Sometimes, when they didn't know the vocabulary, they looked up their dictionaries or asked the teacher or their friends. Even though they still confused with the vocabularies, they keep challenged and defended their opinions bravely. At those condition, some students will help them with gave note for them. It meant, they interaction on the second meeting was imoroved rather than the firs meeting. The students also showed more confidence when they talked in front of their classmates.

In the last meeting, all of the students participated actively during the lesson. Since they already known the rules of the technique, they immediately sat in their group form started from the beginning of the lesson. They thrown the ball excitedly and answered the question bravely. They have no doubt to asked permission to the teacher to gave their opinion in certain thing. They also interacted actively within the group, and they paid attention to the other group. Most of them were being spontaneous by clapped hands after their friends answered the question.

From the observation sheet taken by the researcher, most of the students show enthusiasm in learning English by using Snowball Throwing technique. This is supported by theory from Suprijono $(2010: 33)$ that snowball throwing is a technique that requires active students in teaching and learning activities. The overall result indicated that the students' participation has significantly improved by using Snowball Throwing technique.

\section{CONCLUSION}

Students active participation give the crucial effect to the learning process. It trusted can determine the success of the lesson. This study aimed to investigate the implementation of snowball throwing technique in teaching speaking and to find out the students' participation toward the implementation of snowball throwing. The result showed that snowball throwing technique can be used effectively to improve students' speaking skill through several stages. First, every leader explains the material to their group. Second, every student writing one question about the material. Third, the paper is rolled into a ball and thrown from one student in a group to the other student in another group for approximately 2 minutes. Fourth, after the student gets one ball (one question), he or she is given chance to answer the question. Fifth, every group has their turn to answer the question; the group that gave wrong or incorrect answers and gets the lowest score is given a penalty. Those stages gave the students more chance to interacted in the class. It was very helpful in provide the students with more enjoyable activities which made the students involved in teaching and learning process actively. 


\section{ACKNOWLEDGEMENTS}

First of all, thanks to Allah SWT, for his mercy and guidence in giving me full strength to complete this article. Thanks to my lecturer, Miss Yanuarti Apsari, M.Pd, for all of her support and guidence in helping me to finish my journal. Thanks to my parents, for all support especially for financial support during making this journal. And the last, I would like to thanks to myself for all of the hard work for finish my study.

\section{REFERENCES}

Alshenqeeti, H. (2014). Interviewing as a Data Collection Method: A Critical Review. English Linguistics Research, 3(1). https://doi.org/10.5430/elr.v3n1p39

Aprila, F. (2017). Improving students' participation in speaking english using talk show technique. Pontianak.

Apsari, Y. (2018). Snowball Throwing in Teaching Grammar. Lingual, 10(1), 5259.

Kawulich, B. (2012). Collecting data through observation. Https://Www.Researchgate.Net/Publication/257944783_Collecting_data_through_obser vation, (May). https://doi.org/Janaury 2012

Lambert, V. A., \& Lambert, C. E. (2012). Editorial: Qualitative Descriptive Research -An Acceptable Design. Journal of Nursing Research, 16(4), 255-256.

Nuryati, D., Antoni, R., \& Erippudin. (2015). No TiImproving Students 'Reading Comprehension in Recount Text By Using Snowball Throwing At Grade Viii Smpn 4 Pagaran Tapah Darussalam Provinsi Riautle.

Tesfaye, S., \& Berhanu, K. (2015). Improving Students' Participation in Active Learning Methods: Group Discussions, Presentations And Demonstrations: A Case of Madda Walabu University Second Year Tourism Management Students of 2014. Journal of Education and Practice, 6(22), 29-33. 